\title{
Belarusian case study of P2P lending market digitalization: state-of-the-art, needs and perspectives
}

\author{
Joanna Koczar ${ }^{1}$, Yury Karaleu, ${ }^{2, *}$, and Aliaksandr Dudkin ${ }^{2,3}$ \\ ${ }^{1}$ Wroclaw University of Economics and Business, 53-345, Komandorska Str., 118/120, Wroclaw, \\ Poland \\ ${ }^{2}$ School of Business of Belarusian State University, Oboinaya Str., 7, 220004 Minsk, Belarus \\ ${ }^{3}$ JSC BSB Bank, Pobediteley ave., 23/4, 220004 Minsk, Belarus
}

\begin{abstract}
The paper investigates the present state and prospects of development of the Belarusian market of mutual lending, the business model and the results of the activity of KUBYSHKA crowdlending Internet platform, the possibilities of organizing cooperation between Belarusian banks and crowdlending platforms, obstacles to the development of the market for mutual lending.
\end{abstract}

\section{Introduction}

Since the early 2000 s and with the development of information technology, the increasing level of globalisation, the anonymous nature of the flow of money, a new innovative element of the money market (in the non-banking sector) had emerged - the market for mutual lending or crowdlending. The uniqueness of the crowdlending or marketplace lending (in contrast to other segments of the non-banking sector of the financial market) is the absence of a traditional financial intermediary (primarily a bank) in the process of transferring money from an individual (lender or investor) to the borrower. The latter could be:

- legal entities (basically SMEs) - also called person-to-business lending (P2B lending) - business lending by a private person;

- another individual - also called peer-to-peer lending (P2P lending) - lending by one private person to another $[1,2]$.

The crowdlending world market is basically presented by the Asian market ( $84 \%$ with a turnover of USD420 billion in 2018), the American market (12\% market share with a turnover of USD60 billion) and the European market (3\% market share with a turnover of USD15 billion). The remaining balance of 1\% is split between Africa and Australia [3].

The P2P lending market, which is the object of this survey, is not fundamentally a new stream but it has indeed recently become relatively cheap and easy to find sufficient investors to finance the amount requested by the borrower through the virtual crowdlending platforms. After a loan agreement is concluded between parties (often via the platform), the crowdfunding platform transfers the invested loan amount from the investor to the borrower. In return, the borrower has to repay the loan amount to the lender over a predefined period,

*Corresponding author: yykorolev@sbmt.by 
plus interests. So, credit check, rating, brokering, processing, operation, etc. are handled by the crowdlending platform. Even any payment delay or borrower's inability to pay are usually handled by the platform, without the investors themselves having to intervene, in exchange for a fee (mostly paid by the borrower) [3, 4]. So, crowdlending platforms "epitomise the idea of disintermediated 'middle-man-free' access to finance, especially insofar as platforms are conceived as technological means that allow borrowers to directly access available funding on the one hand, and lenders to invest in specific loans on the other" [5].

The first-ever worldwide launched crowdlending platform named ZOPA (Zone of Possible Agreement) was founded in the UK in 2005. It still remains one of the largest and most authoritative in the world. Over the past 15 years, half a million borrowers have been loaned through ZOPA for a total amount of over GBP5 billion; investors of the site (lenders) received interest income in the amount of more than GBP250 million [6].

In 2006, similar crowdlending platforms PROSPER and LENDING CLUB appeared in the United States. Since that moment, the practice of P2P lending has become the most widespread in the world, both in high-income economies such as UK, USA, Sweden, Australia, Canada, China as well as in emerging economies such as India and Brazil.

Since 2012, similar services have become and appear in Russia. ZAYMIGO, LOANBERRY and Вдолг.py are the most prominent today [7, 8].

Summing up the aforesaid, we consider that interaction between individuals on the mutual landing based on the global Internet, remotely, online, is an innovative digital technology in the field of finance (fintech project), fully correlates with the digital transformation trend in all sectors of the global economy.

\section{Belarusian market of mutual landing}

Belarusian financial market includes the banking system (the main and largest market participant), as well as the non-banking sector (leasing companies, forex companies, insurance organizations, professional participants in the securities market, microfinance organizations, etc.). The National Bank of the Republic of Belarus (National Bank) and the Belarusian Government strongly encourage the development and competition between various participants in the financial market. The intensification of competition and even the preferential development of the non-banking sector were declared in the Strategy for the Development of the Financial Market of the Republic of Belarus until 2020, approved by a joint resolution of the Council of Ministers and the National Bank of March 28, 2017, No. $229 / 6$, as one of the strategic objectives.

Despite the declared goals, the Belarusian market for mutual lending is still in its infancy. Until now, the issues of granting loans between individuals in the Belarusian legislation has not been properly regulated [9]. The work on the preparation of the draft Decree regulating the activities of such services in the Republic of Belarus, initiated by the National Bank back in 2017, has actually been suspended today. At the same time, in the report of the First Deputy Chairman of the Board of the National Bank Sergei Kalechits it is proposed to pay special attention to the development of online borrowing services [9].

\section{Business model and operational results of KUBYSHKA crowdlending Internet platform}

Today, the Belarusian market of mutual lending is represented by a single player professional intermediary KUBYSHKA crowdlending Internet platform, founded by Financial and Analytical Bureau LLC (Holding Company). 
The activity of KUBYSHKA crowdlending Internet platform was launched in December 2016. The National Bank, as the main regulator of the national financial market, was promptly informed by the founder about the start of activities and about the business model of the platform based on online Internet resource www.kubyshka.by [10].

Today 1,300 individuals (borrowers and lenders) are registered as users of the crowdlending Internet platform. Over the period since the beginning of the activity through the Internet site, more than 3,000 loans were issued totalling USD900 thousand (in equivalent). As shown in Fig. 1, the current portfolio of 900 loans by reference to the principal outstanding is equal to USD183 thousand.

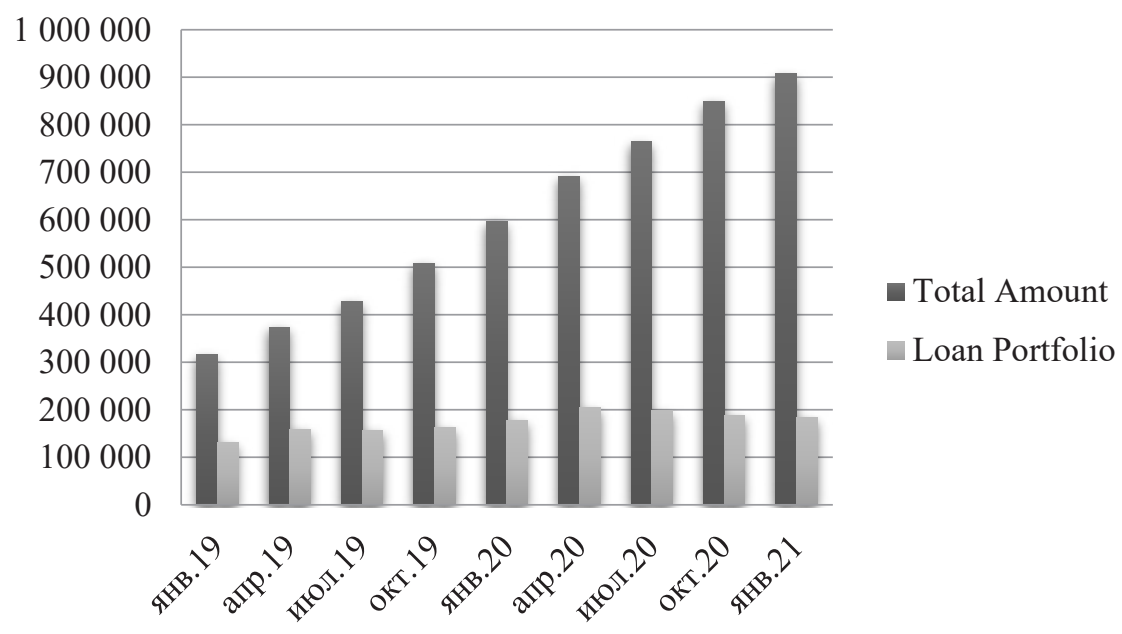

Fig. 1. The dynamic of the loan portfolio and total loan amount, USD (in equivalent).

According to the business model of KUBYSHKA crowdlending Internet platform, the registration of borrowers is carried out after they have signed, in the presence of a representative of the company, a loan adhesion agreement, a user agreement and when the individual's consent to process his/her personal data from the Credit Register is obtained. Registration of lenders is carried out remotely.

Despite the fact that the Holding Company is not a party to the treaty and is not responsible for any financial risks of non-repayment of debts, it assumed the responsibility for assessing the solvency of borrowers and guarantors (if any), assigning a credit rating (basic (from 0.0 to 5.0 ) or advanced rate (from 0.0 to 10.0)) and setting a personal credit limit. As practice has shown, most borrowers undergo an initial assessment of solvency, which does not require supporting documents and certificates, as well as the presence of guarantors, which, as a result, ensures that borrowers receive a basic credit rating. The average ratings of borrowers entering into loan deal in local (BYN) and foreign currency are 3.2 and 3.4, respectively (Fig. 2). 


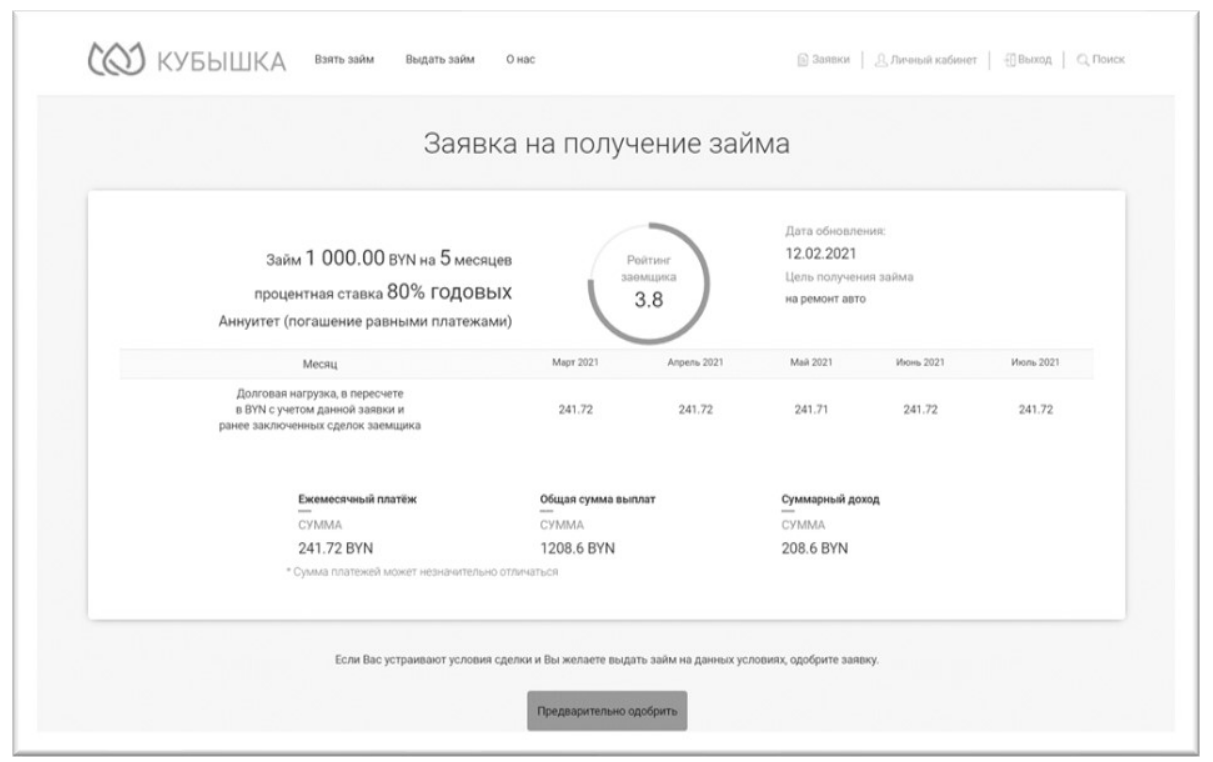

Fig. 2. The interface of loan application in KUBYSHKA crowdlending Internet platform with the attributed credit rating (personal data of the borrower are not presented).

The specific feature of KUBYSHKA crowdlending Internet platform is the assignment of the borrower to set the loan terms and conditions (such as the size of the loan, the loan terms, interest rate, the loan currency) when presenting loan applications to the crowdlending platform. If the lender accepts the submitted loan application, he transfers the money to the borrower. By doing so, the lender joins the loan adhesion agreement and since that moment the loan deal is considered concluded.

The procedure (schedule) for the repayment of loan debt and accrued interests are established automatically when concluding a loan deal using the annuity method.

Settlements between parties for issuing and repaying loans and paying interests are carried out remotely making instant card-to-card money transfers between parties using the "virtual terminal" of the partner bank (OJSC Belgazprombank), which is implemented into KUBYSHKA crowdlending Internet platform.

\section{Preconditions for the development of the market for mutual lending}

The political and socio-economic uncertainty in Belarus, enhanced since the second half of 2020, has become the main reason for the large-scale outflow of deposits of individuals from the banking system. As shown in the Analytical Review of the National Bank "Survey on the implementation of the banking principle "Know your customer" (KYC approach) in relation to attracting term deposits of individuals, in 2020 deposits in foreign currency decreased from USD6.3 billion to USD4.7 billion or more than 25\%; deposits in BYN - from BYN5.2 billion to BYN4.6 billion or by $11.6 \%$ [11] (Fig. 3). 


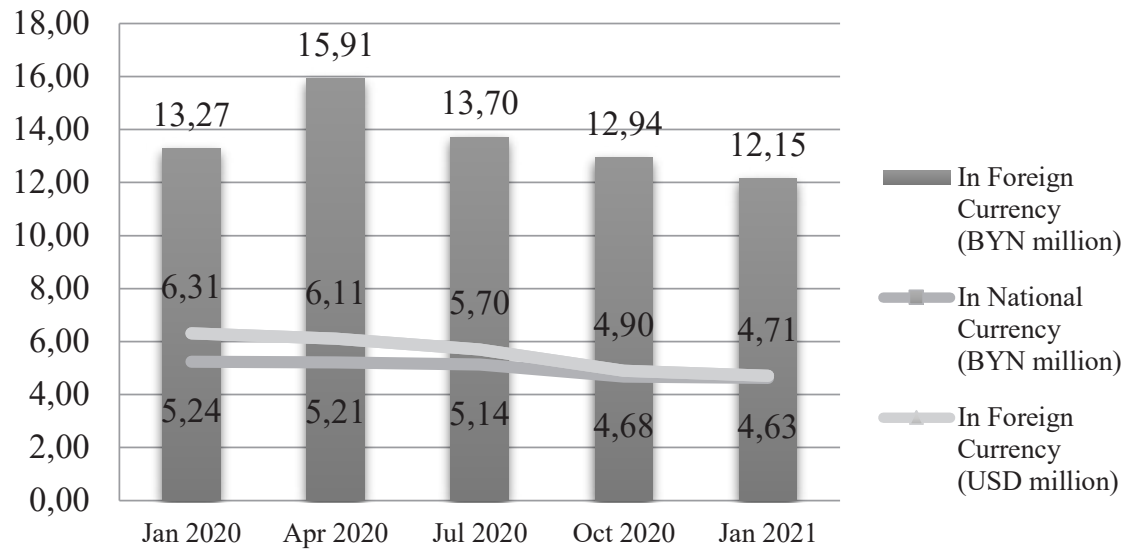

Fig. 3. Dynamic of term deposits in Belarusian banks in 2020.

This, in turn, has led to unstable capital markets, a significant decrease in the liquidity of the banking sector and a reduction of available borrowings for individuals (or caused the total suspension of lending) with a conjoined growth of the borrowing value [12] (Fig 4).

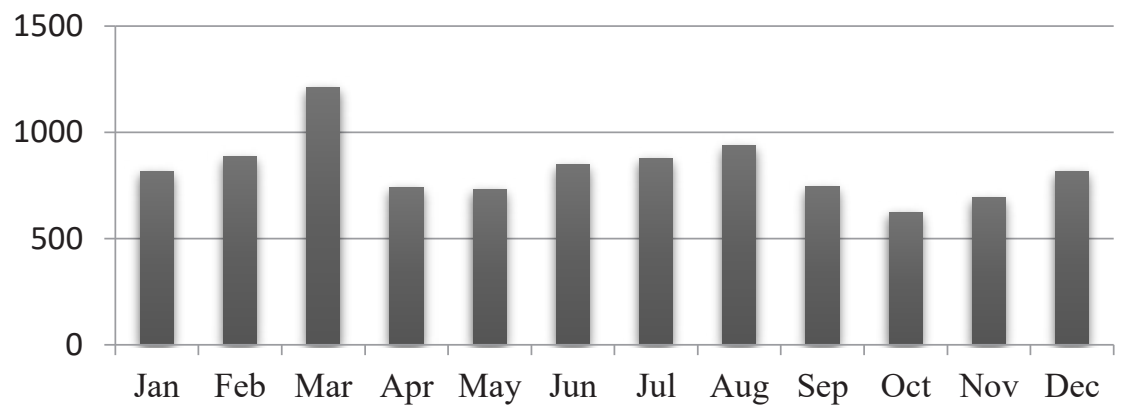

Fig. 4. Dynamic of bank lending to individuals in Belarus in 2020, BYN million.

Such a large-scale decrease in the volume of lending to individuals by banks stimulates individuals to seek alternative sources of financing for their own current needs. Only an insignificant part of the banking customers became clients of KUBYSHKA crowdlending Internet platform and a significant part of them apparently turned to participants of the shadow banking system, qualitative and quantitative evaluation of which is extremely difficult in Belarus due to a lack of information required for monitoring.

At the same time, banking customers with limited access to bank resources, who became users of KUBYSHKA crowdlending Internet platform, as well as previously registered borrowers, fully demonstrated an urgent need for credit resources that lead to rising interest rates for new loan applications.

Fig. 5 below shows the dynamic of interest rates for new loan applications over the past two years. The weighted average interest rates reached a maximum by January 2021: 243\% per annum - for transactions in BYN and 97\% per annum - for transactions in foreign currency. 


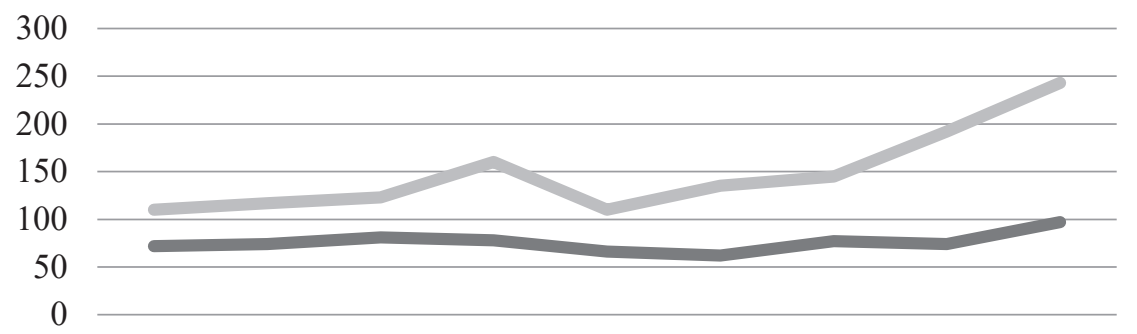

янв.19 апр.19 июл.19 окт.19 янв.20 апр.20 июл.20 окт.20 янв.21

$\longrightarrow$ In Foreign Currency $=$ In BYN

Fig. 5. The dynamic of interest rates for new loan applications over the past two years.

The described situation would not have been possible in a balanced market environment, providing free access of individuals with a higher credit rating to credit resources through crowdlending Internet platforms with a reasonable personal credit limit and sensible interest rates.

On the other hand, such a rise in interest rates in the absence of obvious factors of a sharp deterioration of borrowers' solvency (proved by rational level of resulting risk-reward ratio) is quite attractive for another group of KUBYSHKA crowdlending Internet platform lenders. The profitability of lenders' investments is much higher than the interest rates on bank deposits and investments in securities on the Belarussian stock market. Simultaneously, lending of investments on crowdlending platforms is less than the risk of operations in the Forex market and, most importantly, it is controlled and managed by the lender himself.

The attractiveness of such a model of personal investments is illustrated by the statistics of overdue and toxic debts. As of February 1, 2021, according to KUBYSHKA crowdlending Internet platform data, more than $81 \%$ of the funds invested by creditors were repaid in full amount including interest payments, and in some cases - with penalties and fines. The remainder of the current portfolio is classified as standard loans $-7.8 \%$, loans with insignificant (often technical) overdue $-1.8 \%$, toxic loans with more than 90 days overdue $9.4 \%[10]$.

In order to reduce the risk of non-repayment of issued loans, the Holding Company has assumed the responsibility of assisting creditors in the event of defaults or delay. In particular, the proceedings of disputes between borrowers and lenders are carried out in the Arbitration Court, established at the Financial and Analytical Bureau LLC and registered in the manner established by the legislation.

Despite the attractiveness of the model of mutual lending for both borrowers and lenders, as described earlier, a significant part of the personal funds is withdrawn from financial turnover and transferred to the unregulated shadow borrowing market and criminalization.

\section{Needs and Perspectives of the development of Belarusian P2P lending market}

The KUBYSHKA crowdlending Internet platform extensive operation experience in the real Belarusian economic environment has revealed a number of problems that demand the immediate solution for the further development of P2P technology. For example, the cooperation between banks and crowdlending platforms, in addition to the infancy of the market for mutual lending and the absence of a large number of participants, is seriously hampered by the fears of banks related to their joined cross-services. Some experts raised 
concerns about ambiguous interpretation by the National Bank of the Republic of Belarus of the possibility and legality of providing cross-services by banks together with crowdlending platforms. In our opinion, such fears are not justified, because, in a similar regime, Belarusian banks have been selling services of insurance companies at their points of sale for several years. This kind of cross-sales does not raise doubts because it is an established practice that has never been questioned. In addition, international experience demonstrates only the positive effects of the proposed collaboration.

Among other urgent problems in the development of P2P technologies, the following can be distinguished:

- Organization of monitoring and control of crowdlending platforms as professional financial intermediaries;

- A legal regulation of lending deals between individuals;

- The implementation of personal bankruptcy;

- A legal regulation of the activity of collection agencies;

- The inclusion of the history of borrowings on crowdlending platforms in the credit history of borrowers;

- The development of risk insurance of non-recovery funds, etc. [1].

For example, to ensure enforcement in the event of borrower's default, it seems appropriate to amend Law On economic insolvency (bankruptcy) dated July 13, 2012, No. 415-3 in the part concerning the introduction of the institution of personal bankruptcy. A similar institute exists in many countries of the world: in the USA, Germany, England, Sweden, Denmark, Spain, and not so long ago it appeared in the Russian Federation [13].

To qualify the issues of granting loans between individuals as an entrepreneurial activity, it is necessary to clarify the legality of actions to provide no more than two loans by an individual without registration as an entrepreneur, which, in our opinion, can be regarded in the situation under consideration as a definition of the concept of 'on a regular basis' [9].

Each of the highlighted problems is a range of measures and activities, new legal mechanisms that deserve separate consideration and are just beyond the scope of this article.

\section{Conclusions}

According to the crowdfunding-platforms.com, the European crowdlending market had in 2013-2018 yearly growth of $+70 \%$ on average. Even despite the expected slowdown of its growth over the next years because of tightening of monetary and credit conditions in response to COVID-19 and increased inflationary pressures, specialists consider the value of the European crowdlending market equal to USD38 billion in 2023 representing a forecasted yearly growth of $+16 \%$ on average [3].

Taking into account such prospects for the development of the P2P crowdlending market, an incentive for its development at the national level could be the development and enactment of a new special legal act regulating the activities of crowdlending platforms (services) as a professional intermediary, as well as amending the Law On economic insolvency (bankruptcy) and a number of other regulatory legal acts. The creation of a full-fledged regulatory legal framework will fully legalize mutual lending, ensure proper state control over this market, and increase budget revenues by including the corresponding income of individuals in the taxable base.

Integration of Belarusian banking system with crowdlending Internet platforms and collaboration between them will allow maintaining and increasing the client base, more effectively using the intellectual potential of the staff and the existing territorial network of points of sale. All this will ensure high quality, speed and convenience in managing the personal finances of individuals, and will significantly increase the availability of modern financial services for them. 


\section{Acknowledgements}

The article has been prepared as a part of the project financed by the Ministry of Science and Higher Education in Poland under the programme „Regional Initiative of Excellence” 20192022 project number $015 / \mathrm{RID} / 2018 / 19$.

\section{References}

1. Y. Y. Karaleu, A. B. Dudkin, Finance architecture: new solutions in the digital economy, 272 (2019)

2. V. A. Kuznetsov, Money and credit, 1, 65 (2017)

3. Crowdlending Guide: What is it and how to invest? https://crowdfundingplatforms.com/

4. A. B. Dudkin, Business. Innovation. Economy, 1, 52 (2017)

5. V. Bavoso, J Bank Regul, 21, 395 (2020)

6. ZOPA, https://www.zopa.com

7. K. Treskova, P2P lending: what is it, https://brobank.ru/

8. A. B. Dudkin, Legal world, 6, 78 (2017)

9. D. L. Kalechits. Ensuring financial stability in 2020 and targets for 2021, https://www.nbrb.by/

10. KUBYSHKA, https://kubyshka.by/

11. Analytical review of the National Bank of the Republic of Belarus "Survey on the implementation of the banking principle "Know your customer" (in relation to attracting time deposits (deposits) of individuals), https://www.nbrb.by/

12. Statistical Bulletin of the National Bank of the Republic of Belarus, https://www.nbrb.by/

13. Y. Y. Karaleu, Innovative development of the economy: entrepreneurship, education, science (2017) 